\title{
The distribution of primary cesarean section indication at a university hospital: ten-year experience and potential lessons to be taken to decrease cesarean section rates
}

\author{
Semir Köse', Aslı Akdöner², Sabahattin Altunyurt ${ }^{3}$ \\ ${ }^{1}$ Perinatology Clinic, Buca Obstetrics and Pediatrics Hospital, İzmir, Turkey \\ ${ }^{2}$ Clinic of Gynecology and Obstetrics, Bitlis Güroymak State Hospital, Bitlis, Turkey \\ ${ }^{3}$ Department of Gynecology and Obstetrics, Faculty of Medicine, Dokuz Eyliil University, İzmir, Turkey
}

\begin{abstract}
Objective: Although cesarean section can be a life-saving practice for pregnant woman and fetus, great increase in the rates of cesarean section in the recent years has made its indications questionable. Primary cesarean section (PCS) is the main source of total cesarean section pool. In our study, we aimed to investigate the distributions of PCS indications and to determine the case characteristics of the groups.

Methods: A full cohort of delivery room records for PCS carried out between January 1, 2007 and January 1, 2017 at the Hospital of Dokuz Eylül University was analyzed. PCS cases were separated into two groups as singleton and multiple pregnancies first, and then singleton pregnancies were separated into term-preterm and primiparous-multiparous groups for advanced sub-group analyses.

Results: A total of 3284 PCS cases from a ten-year period were accessed. Of the cases, $263(8.0 \%)$ were twin pregnancy, $11(0.3 \%)$ were triplet pregnancy, and $3010(92.7 \%)$ were singleton pregnancy. Of $494(15.0 \%)$ preterm cases, $105(21.3 \%)$ were in multiple pregnancy group and $389(78.7 \%)$ were in the singleton pregnancy group. While dystocia $(41.6 \%)$ was the most common indication among term cases, it was fetal distress (35.4\%) among the preterm cases. When the cases were compared according to the parity, the rank and frequency of the indication were varying significantly. Dystocia $(40.2 \%)$ was the most common indication among the primiparous cases while it was fetal distress (23.0\%) among the multiparous cases. Conclusion: Dystocia, which is the greatest indication among PCS categories, is the hardest indication to standardize due to the fact that its diagnosis criteria are controversial and determining these criteria is very subjective. A different path should be followed for the solution of fetal distress issue since it is the most common indication in preterm labor cases. Breech presentations and the suspected macrosomic infant seem to be the first goal of the measures to be taken to decrease the need of cesarean section.
\end{abstract}

Keywords: Primary cesarean section, dystocia, fetal distress, macrosomia.

\section{Özet: Bir üniversite hastanesinin primer sezaryen endikasyon dağııımı: On yıla ait tecrübe ve sezaryen doğum oranlarını azaltmaya yönelik çıkarılabilecek dersler}

Amaç: Gebe ve fetüs için hayat kurtarıcı olabilmesine rağmen sezaryen doğum oranlarında son yıllardaki büyük artış, endikasyonlarının sorgulanmasını gündeme getirmiştir. Primer sezaryen (PS) doğum toplam sezaryen doğum havuzunun ana kaynağıdır. Araştırmamızda PS endikasyon dağılımlarının incelenmesi ve gruplara ait olgu özelliklerinin belirlenmesi amaçlanmıştır.

Yöntem: Dokuz Eylül Üniversitesi Hastanesi'nde 1 Ocak 2007 ile 1 Ocak 2017 tarihleri arasında gerçekleştirilmiş olan PS doğumlara ait doğumhane kayıtlarının tam bir kohortu incelendi. PS olguları daha sonra tekil gebelikler ve çoğul gebelikler, tekil gebelikler de term-preterm ve primipar-multipar olarak ikiye ayrilarak ileri alt grup analizleri yapildı.

Bulgular: On yıllık bir dönemden 3284 PS doğuma ait bilgilere ulaşıldı. Olguların 263 'ü (\% 8.0) ikiz gebelik, 11 ’i (\%0.3) üçüz gebelik olup 3010 olgu (\%92.7) ise tekil gebeliklere aitti. Preterm olgu sayısı 494 (\% 15.0) olup bu olguların 105'i (\%21.3) çoğul gebelikler, 389 olgu (\%78.7) tekil gebelikler grubunda yer alıyordu. Term olgularda distosi (\% 41.6), preterm olgularda ise fetal distres (\%35.4) en sik rastlanan endikasyonlar olarak saptandı. Pariteye göre karşılaştırıldığında endikasyon sıralaması ve sıklıkları önemli değişkenlikler göstermekte idi. Primipar olgularda distosi (\% 40.2), multipar olgularda ise fetal distres (\%23.0) en büyük endikasyon grubunu oluşturmakta idi.

Sonuç: PS kategorilerinin en büyüğü olan distosi, tanı kriterlerinin tartışmalı olması ve bu kriterlerin saptanmasındaki öznellik boyutu nedeniyle en zor standardize edilecek endikasyon olarak öne çıkmaktadır. Fetal distres preterm doğum olgularında en sık rastlanan endikasyon grubu olması nedeni ile çözümünde farklı bir yol izlenmesi gereken bir başlıktır. Makat prezentasyonlar ve makrozomik bebek şüphesi olguları sezaryen doğum ihtiyacını azaltmaya yönelik tedbirlerin ilk hedefi olarak görünmektedir.

Anahtar sözcükler: Primer sezaryen, distosi, fetal distres, makrozomi.
Correspondence: Semir Köse, MD. Perinatology Clinic, Buca Obstetrics and Pediatrics Hospital, İzmir, Turkey. e-mail: semirkose@yahoo.com

Received: June 16, 2018; Accepted: December 3, 2018

Please cite this article as: Köse S, Akdöner A, Altunyurt S. The distribution of primary cesarean section indication at a university hospital: ten-year experience and potential lessons to be taken to decrease cesarean section rates. Perinatal Journal 2018;26(3):124-134. @2018 Perinatal Medicine Foundation
Available online at: www.perinataljournal.com/20180263005 doi: $10.2399 /$ prn. 18.0263005 QR (Quick Response) Code:

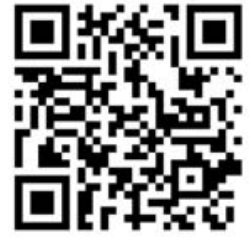




\section{Introduction}

The rates of cesarean section have been increasing in Turkey as in the entire world and even much more rapidly. ${ }^{[1,2]}$ According to OECD data, Turkey has become the number one country as of 2015 with the highest rate for cesarean section with its rate of 531 cesarean section out of 1000 live births. ${ }^{[2]}$ Cesarean sections can be categorized in two groups which are primary and repeat. ${ }^{[3]}$ Primary cesarean section is defined as the first occurrence of cesarean section, and it is called "repeat" when the patient has a history of cesarean section or "former" cesarean section as it is preferred in Turkey.

Therefore, primary cesarean sections (PCS) are the main source of total cesarean section pool. ${ }^{[3]}$ Barber et al. reported that PCS cases are responsible for $50 \%$ of the increase in cesarean section rates. ${ }^{[4]}$ PCS' have widelyaccepted indications; $;^{[1,3]}$ however, the distribution of the indications may vary depending on the countries, centers and even the physicians. ${ }^{[5]}$

Cesarean section has higher morbidity and mortality rates than the vaginal labor. ${ }^{[6]}$ Cesarean section increases the risks of uterine rupture, placenta previa, placenta accreta, hemorrhage, hysterectomy and maternal mortality in the further pregnancies. ${ }^{[7]}$ Therefore, decreasing PCS rates in a safe way without risking maternal and fetal health is among the primary health targets in the world $^{[8]}$ and Turkey. ${ }^{[9]}$

PCS indications are considered in two main topics which are maternal and fetal indications. ${ }^{[10,11]}$ The analysis of the distribution of these indications has a critical significance to determine effective strategies for decreasing PCS needs. Among these indications, the most common and subjective one is dystocia ${ }^{[1,10]}$ and it is an indication also used as non-progressive labor or cephalopelvic disproportion in the clinical practice. Electronic fetal monitorization (EFM), which is routinely used for the evaluation and follow-up of the well-being of fetus during labor, is criticized for increasing PCS rates without providing any significant improvement in the newborn outcomes. ${ }^{[12]}$ The changes and patterns seen in fetal heart rates during labor follow-up and interpreted as fetal distress are the second greatest category among PCS indications. ${ }^{[1,8,1]]}$ Multiple pregnancies increase as assisted reproductive technologies improve and become prevalent. ${ }^{[13]}$ Multiple pregnancies and breech presentations constitute a significant part of PCS indications, and represent an aspect of obstetrics which diminishes slowly.
Delivering all twin pregnancies by cesarean section is an important question of debate whether it decreases perinatal mortality or not. ${ }^{[14]}$ One of the focuses in the studies to decrease PCS rates safely is the safety of external cephalic version in breech presentations. ${ }^{[15]}$ In breech presentations, trying vaginal labor in both nulliparous and multiparous pregnant women is an important question of debate. ${ }^{[16,17]}$ Large infant (macrosomic fetus) is included in the top 5 PCS indication category in clinical practice. ${ }^{[1,9]}$ Another aspect of macrosomic fetus category is that it may be included in a different scenario in PCS labors due to dystocia except PCS labors directly due to macrosomic fetus. While fetal weights which is $4500 \mathrm{~g}$ and above for diabetic pregnant women and $5000 \mathrm{~g}$ and above for non-diabetic pregnant women are required for the macrosomia definition in the standard treatment guidelines, an expected birth weight of $4000 \mathrm{~g}$ is chosen as a more common cautionary threshold in practice. ${ }^{[18,19]}$ The medicolegal concerns related with shoulder dystocia especially and brachial plexus paralysis and asphyxia which may develop afterwards compel many obstetricians to make the decision for cesarean section as from expected fetal weight of $400 \mathrm{~g} .{ }^{[18,19]}$ Evaluating PCS indication category due to macrosomic fetus and determining its relative weight will support the efficacy of labor induction efforts to decrease PCS rates safely in pregnancies with fetuses over the expected weights which are close to the term, and the determination of sub-groups where it can be successful.

\section{Methods}

This study analyzed the full cohort of delivery room records for PCS cases carried out between January 1, 2007 and January 1, 2017 at the Department of Obstetrics and Gynecology of Dokuz Eylül University. For that purpose, all PCS cases with indications which were seen clearly were included in the study. PCS cases were separated into two groups as singleton and multiple pregnancies, and then singleton pregnancies were separated into term-preterm and primiparous-multiparous groups for advanced sub-group analyses. Former cesarean section and postmortem cesarean section cases were excluded from the study. In order to comply with the terminology in the literature, exceptional cases below $500 \mathrm{~g}$ and 24 weeks of gestation were not included. The study was approved by Ethics Committee for Non-Invasive Researches of Dokuz Eylül University (4087-GOA-2018/16-06). 


\section{Statistical analyses}

Statistical analyses were performed by using SPSS v.22 (SPSS Inc., Chicago, IL, USA). The compatibility of variables to normal distribution was analyzed by visual and analytical methods (Kolmogorov-Smirnov / ShapiroWilk tests). Descriptive statistics were presented by selecting mean and standard deviation values for the variables exhibiting normal distribution. The mean values of constant variables were compared by one-way ANOVA test among the groups more than two. The homogeneity of variances was analyzed by Levene's test. When significant difference was found between the groups, post-hoc pairwise comparisons were done by Tukey and Games-Howell tests. When constant variables did not exhibit any normal distribution, they were compared by Kruskal-Wallis test. The presence of difference among the groups in frequency analyses were compared by using either chi-square or Fisher's test. When $\mathrm{p}$ value was below 0.05 , the results were considered statistically significant.

\section{Results}

A total of 3284 PCS labors were carried out between January 1, 2007 and January 1, 2017 in a period of ten years. Of these cases, $263(8.0 \%)$ were twin pregnancy, $11(0.3 \%)$ were triplet pregnancy, and $3010(92.7 \%)$ were singleton pregnancy. The total number of preterm cases was $494(15.0 \%)$, and 105 (21.3\%) of them were in multiple pregnancy group while $389(78.7 \%)$ of them were in the singleton pregnancy group. While $38.3 \%$ of the multiple pregnancies resulted in preterm labor, only $12.9 \%$ of the singleton pregnancies resulted in preterm labor. When all cases were considered, mean gestational age was $29.2 \pm 5.3$ (range: 15.0 to 51.0), and mean birth weight of newborns was $3123 \pm 812$ (range: 502 to 5580 ) g. Of the cases, $2106(64.1 \%)$ were primigravida and 1178 (35.9\%) were multigravida. Considering the cases in terms of previous history of live birth, 2604 (79.3\%) cases were primiparous and $680(20.7 \%)$ cases were multiparous. $16.7 \%$ of the pregnant women (548 cases) were 35 years old or above.

PCS indication categories are presented in Table 1. The number of obstetric indication categories with frequency of $1 \%$ and above was 9 (Table 1). The greatest category in this group and the greatest group among PCS' was dystocia (36.0\%). In our clinic, cephalopelvic disproportion and non-progressive labor were pre- ferred as two sub-definitions for dystocia indication. Due to maternal problems, PCS practices were categorized under 6 main topics (Table 1). The greatest indication category in this group was severe preeclampsia (78 cases, $2.4 \%$ ). Indication types with lower than $1 \%$ frequency were categorized under 15 topics (Table 1). Placenta previa marginalis was the greatest group among these rare reasons. When they were all considered, 25 indication types were seen (Table 1).

In term cases, dystocia was found to be the most common indication category in all years (Table 2 and Fig. 1). The frequency of dystocia indication was the highest (48.4\%) in 2011 while it was the lowest (19.5\%) in 2016 (Table 2). The ranking of dystocia, fetal distress, breech presentation, twin pregnancy and macrosomic fetus changed after first 2 years and macrosomic fetus category reached to rank 4 in 2009, 2010 and 2011, and rank 2 in 2016 (Table 2 and Fig. 1). Twin pregnancies regressed to rank 5 as of 2009 , and stayed at this rank except 2012 where it was not within top 5 (Table 2). Although the absolute number of twin pregnancies seemed to decrease beginning from 2010, the decrease was not statistically significant: Ninety-six cases between 2007 and 2010 vs. 69 cases between 2011 and $2016(\mathrm{p}=0.06)$.

In preterm cases, fetal distress was found to be the most common indication category except 2009 (Table 2 and Fig. 2). While fetal distress had a rate of 3.3\% among all PCS' in preterm cases in 2007, it increased to $8.0 \%$ in 2016 . Dystocia, which was the greatest category of term cases, could only manage to be in top 5 groups of preterm cases between 2007 and 2012 (Table 2). Although the ranks changed in some years, fetal distress, breech presentation and twin pregnancies were top three categories in preterm cases (Table 2 and Fig. 2). Unlike term cases, placental attachment anomalies and detachment were always in top 5 categories in preterm pregnancies.

When primiparous and multiparous cases were compared, top 5 indication ranks and their frequencies were varying significantly. While the top five indications for primiparous cases were dystocia $(40.2 \%)$, fetal distress $(18.9 \%)$, breech presentation $(11.2 \%)$, twin pregnancies $(8.3 \%)$ and macrosomic fetus $(5.6 \%)$, they were fetal distress $(23.0 \%)$, dystocia (19.9\%), breech presentation (14.5\%), macrosomic fetus (13.6\%) and twin pregnancies $(6.6 \%)$ for multiparous cases. When the groups with maternal age above and below 35-year-old were com- 
Table 1. The distribution of indications of primary cesarean section cases in total cohort.

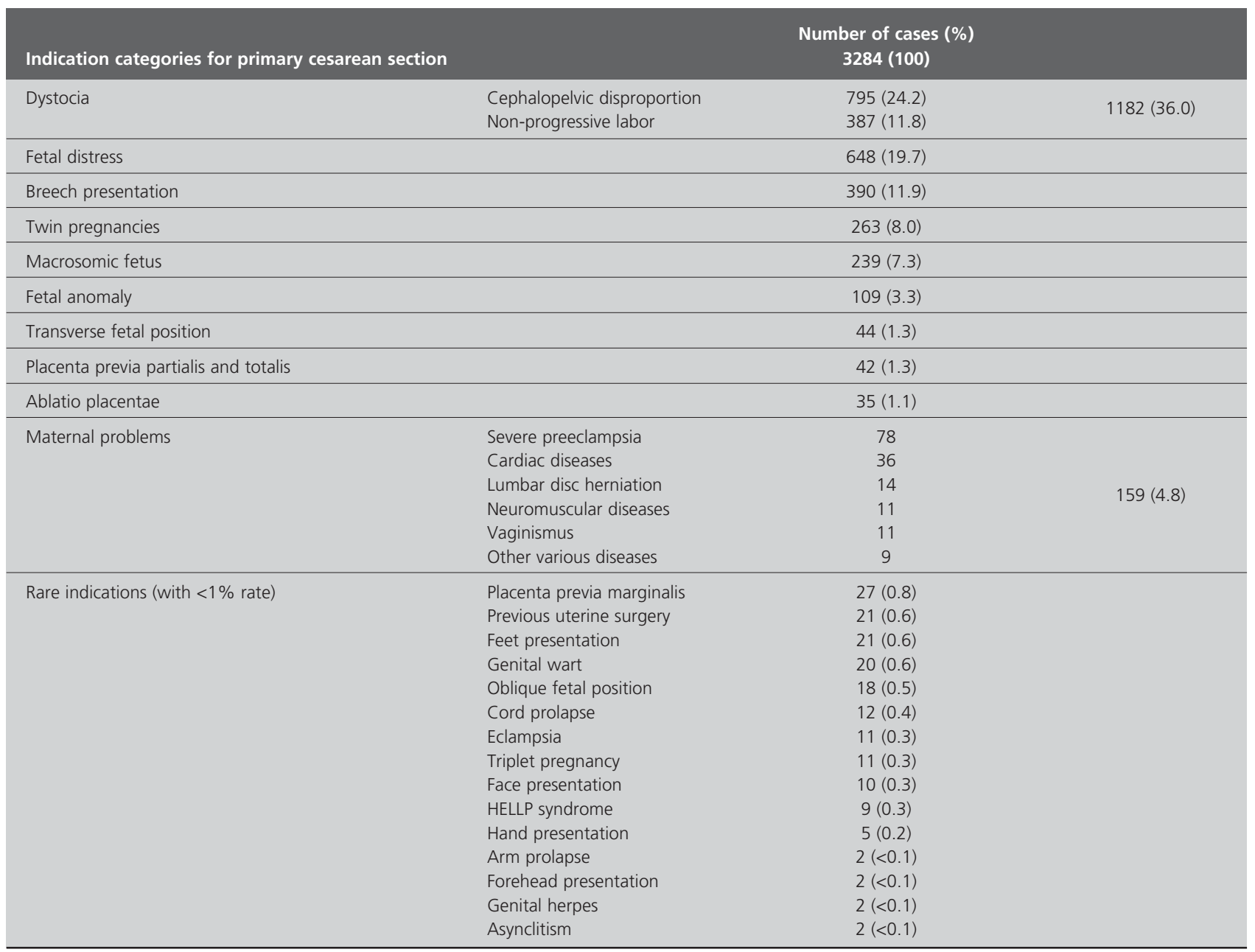

pared, top 3 categories were same (dystocia, fetal distress, breech presentation); however, 4th category was twin pregnancies in the group with maternal age of $<35$ while it was macrosomic fetus in the group with maternal age of $\geq 35$. The rate of macrosomic fetus was $6.9 \%$ in cases with the maternal age of $<35$ and $8.9 \%$ in cases with the maternal age of $\geq 35$. Dystocia was the greatest category in both groups ( $36.4 \%$ vs. $34.1 \%$; $=0.422)$, and first 5 indication ranking did not change.

When maternal, fetal and obstetric characteristics of top 5 indication groups were compared among the groups, there was no significant difference among the groups in terms of mean maternal age (Table 3). Newborn weight was significantly higher in macrosomic fetus group than all other groups $(\mathrm{p}<0.0001)$, and it was significantly higher in dystocia group than fetal distress $(\mathrm{p}<0.0001)$ and breech presentation $(\mathrm{p}<0.0001)$ groups.

Primiparous case rate was higher in fetal distress, breech presentation and macrosomic fetus groups than dystocia and twin pregnancy groups (Table 4). Male fetus rate was higher in macrosomic fetus group than breech presentation group. Preterm case rate was higher in twin pregnancy and fetal distress groups than the other groups. Preterm case rate was also higher in twin pregnancy group than the fetal distress group $(\mathrm{p}=0.008)$ (Table 4). The rate of pregnancy obtained by assisted reproductive technologies was higher than all other groups; the rates of pregnancies obtained by spontaneous pregnancy and in vitro fertilization / intrauterine insemination were not different among other groups (Table 4). 
Table 2. Distribution of top 5 indication categories of primary cesarean section in term and preterm cases by years.

\begin{tabular}{|c|c|c|}
\hline $\begin{array}{l}\text { Years / Number of primary cesarean } \\
\text { section cases ( } \% \text { in cohort) }\end{array}$ & $\begin{array}{l}\text { Top } 5 \text { indication groups in term cases } \\
\text { Number of cases (\%) }\end{array}$ & $\begin{array}{l}\text { Top } 5 \text { indication groups in preterm cases } \\
\text { Number of cases (\%) }\end{array}$ \\
\hline 2007 / 436 (13.2) & $\begin{array}{l}\text { 1. Dystocia } 189 \text { (43.3) } \\
\text { 2. Fetal distress } 62(14.2) \\
\text { 3. Breech presentation } 43(9.9) \\
\text { 4. Twin pregnancy } 26(5.6) \\
\text { 5. Macrosomic fetus } 19 \text { (4.4) }\end{array}$ & $\begin{array}{l}\text { 1. Fetal distress } 17 \text { (3.9) } \\
\text { 2. Twin pregnancy } 14(3.2) \\
\text { 3. Breech presentation } 7 \text { (1.6) } \\
\text { 4. Dystocia } 3(0.7) \\
\text { 5. Placenta previa } 2(0.5)\end{array}$ \\
\hline $2008 / 381$ (11.6) & $\begin{array}{l}\text { 1. Dystocia } 124 \text { (32.5) } \\
\text { 2. Fetal distress } 74 \text { (19.4) } \\
\text { 3. Breech presentation } 48 \text { (12.6) } \\
\text { 4. Twin pregnancy } 26(6.8) \\
\text { 5. Macrosomic fetus } 10 \text { (2.6) }\end{array}$ & $\begin{array}{l}\text { 1. Fetal distress } 23(6.0) \\
\text { 2. Twin pregnancy } 15(4.1) \\
\text { 3. Breech presentation } 3(0.8) \\
\text { 4. Transverse fetal position } 2(0.5) \\
\text { 5. Ablatio placentae } 2(0.5)\end{array}$ \\
\hline 2009 / 329 (10.0) & $\begin{array}{l}\text { 1. Dystocia } 90(27.4) \\
\text { 2. Fetal distress } 79(24.0) \\
\text { 3. Breech presentation } 32(9.7) \\
\text { 4. Macrosomic fetus } 24(7.3) \\
\text { 5. Twin pregnancy } 16(4.9)\end{array}$ & $\begin{array}{l}\text { 1. Twin pregnancy } 19(5.8) \\
\text { 2. Fetal distress } 18(5.5) \\
\text { 3. Breech presentation } 9(2.7) \\
\text { 4. Triplet pregnancy } 2(0.6) \\
\text { 5. Ablatio placentae } 2(0.6)\end{array}$ \\
\hline 2010 / 538 (16.4) & $\begin{array}{l}\text { 1. Dystocia } 204 \text { (37.9) } \\
\text { 2. Fetal distress } 84(15.6) \\
\text { 3. Breech presentation } 40(7.4) \\
\text { 4. Breech presentation } 32(5.9) \\
\text { 5. Twin pregnancy } 28 \text { (5.2) }\end{array}$ & $\begin{array}{l}\text { 1. Fetal distress } 24(4.5) \\
\text { 2. Twin pregnancy } 17(3.2) \\
\text { 3. Breech presentation } 9(1.7) \\
\text { 4. Ablatio placentae } 5(0.9) \\
\text { 5. Fetal anomaly } 4(0.7)\end{array}$ \\
\hline 2011 / 337 (10.3) & $\begin{array}{l}\text { 1. Dystocia } 163 \text { (48.4) } \\
\text { 2. Fetal distress } 33(9.8) \\
\text { 3. Breech presentation } 29(8.6) \\
\text { 4. Macrosomic fetus } 16(4.8) \\
\text { 5. Twin pregnancy } 10(2.9)\end{array}$ & $\begin{array}{l}\text { 1. Fetal distress } 20 \text { (5.9) } \\
\text { 2. Breech presentation } 6(1.8) \\
\text { 3. Twin pregnancy } 5(1.5) \\
\text { 4. HELLP syndrome } 2(0.6) \\
\text { 5. Placenta previa } 2(0.6)\end{array}$ \\
\hline 2012 / 183 (5.6) & $\begin{array}{l}\text { 1. Dystocia } 70(38.2) \\
\text { 2. Fetal distress } 17(9.3) \\
\text { 3. Breech presentation } 15(8.2) \\
\text { 4. Fetal anomaly } 9(4.9) \\
\text { 5. Macrosomic fetus } 8 \text { (4.4) }\end{array}$ & $\begin{array}{l}\text { 1. Fetal distress } 12(6.6) \\
\text { 2. Breech presentation } 6(3.3) \\
\text { 3. Twin pregnancy } 4(2.2) \\
\text { 4. Dystocia } 3(1.6) \\
\text { 5. Ablatio placentae } 2(1.1)\end{array}$ \\
\hline $2013 / 217$ (6.6) & $\begin{array}{l}\text { 1. Dystocia } 81 \text { (37.3) } \\
\text { 2. Breech presentation } 24 \text { (11.1) } \\
\text { 3. Fetal distress } 18(8.3) \\
\text { 4. Macrosomic fetus } 17 \text { (7.8) } \\
\text { 5. Twin pregnancy } 10(4.6)\end{array}$ & $\begin{array}{l}\text { 1. Fetal distress } 9(4.1) \\
\text { 2. Breech presentation } 7(3.2) \\
\text { 3. Twin pregnancy } 5(2.3) \\
\text { 4. Ablatio placentae } 2(0.9) \\
\text { 5. Placenta previa } 2(0.9)\end{array}$ \\
\hline 2014 / 290 (8.8) & $\begin{array}{l}\text { 1. Dystocia } 96 \text { (33.1) } \\
\text { 2. Macrosomic fetus } 47(16.2) \\
\text { 3. Fetal distress } 35(12.1) \\
\text { 4. Breech presentation } 28(9.7) \\
\text { 5. Twin pregnancy } 12(4.1)\end{array}$ & $\begin{array}{l}\text { 1. Fetal distress } 14(4.8) \\
\text { 2. Breech presentation } 8(2.8) \\
\text { 3. Twin pregnancy } 6(2.1) \\
\text { 4. Fetal anomaly } 4(1.4) \\
\text { 5. HELLP syndrome } 2(0.7)\end{array}$ \\
\hline 2015 / 286 (8.7) & $\begin{array}{l}\text { 1. Dystocia } 87 \text { (30.4) } \\
\text { 2. Fetal distress } 45 \text { (15.7) } \\
\text { 3. Breech presentation } 30 \text { (10.5) } \\
\text { 4. Macrosomic fetus } 19 \text { (6.6) } \\
\text { 5. Twin pregnancy } 16(5.6)\end{array}$ & $\begin{array}{l}\text { 1. Fetal distress } 15(5.2) \\
\text { 2. Twin pregnancy } 5(1.7) \\
\text { 3. Breech presentation } 4(1.4) \\
\text { 4. Cord prolapse } 2(0.7) \\
\text { 5. Placenta previa } 2(0.7)\end{array}$ \\
\hline $2016 / 287$ (8.7) & $\begin{array}{l}\text { 1. Dystocia } 56 \text { (19.5) } \\
\text { 2. Macrosomic fetus } 47 \text { (16.3) } \\
\text { 3. Breech presentation } 38 \text { (13.2) } \\
\text { 4. Fetal distress } 26 \text { (9.1) } \\
\text { 5. Twin pregnancy } 21 \text { (7.3) }\end{array}$ & $\begin{array}{l}\text { 1. Fetal distress } 23(8.0) \\
\text { 2. Breech presentation } 7(2.4) \\
\text { 3. Twin pregnancy } 4(1.4) \\
\text { 4. Placenta previa } 4(1.4) \\
\text { 5. Ablatio placentae } 4(1.4)\end{array}$ \\
\hline
\end{tabular}




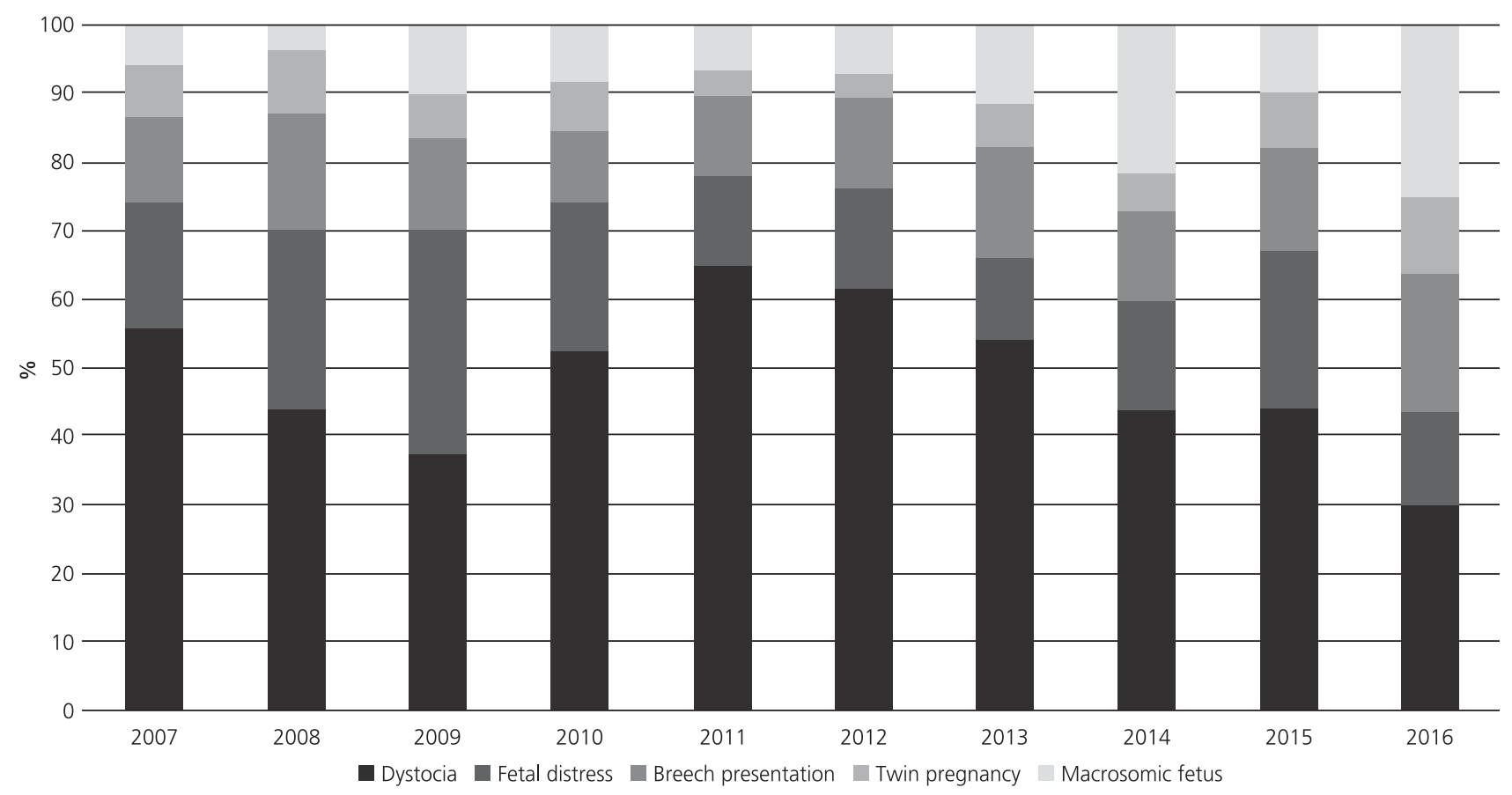

Fig. 1. Top 5 indication categories of primary cesarean section in term cases.

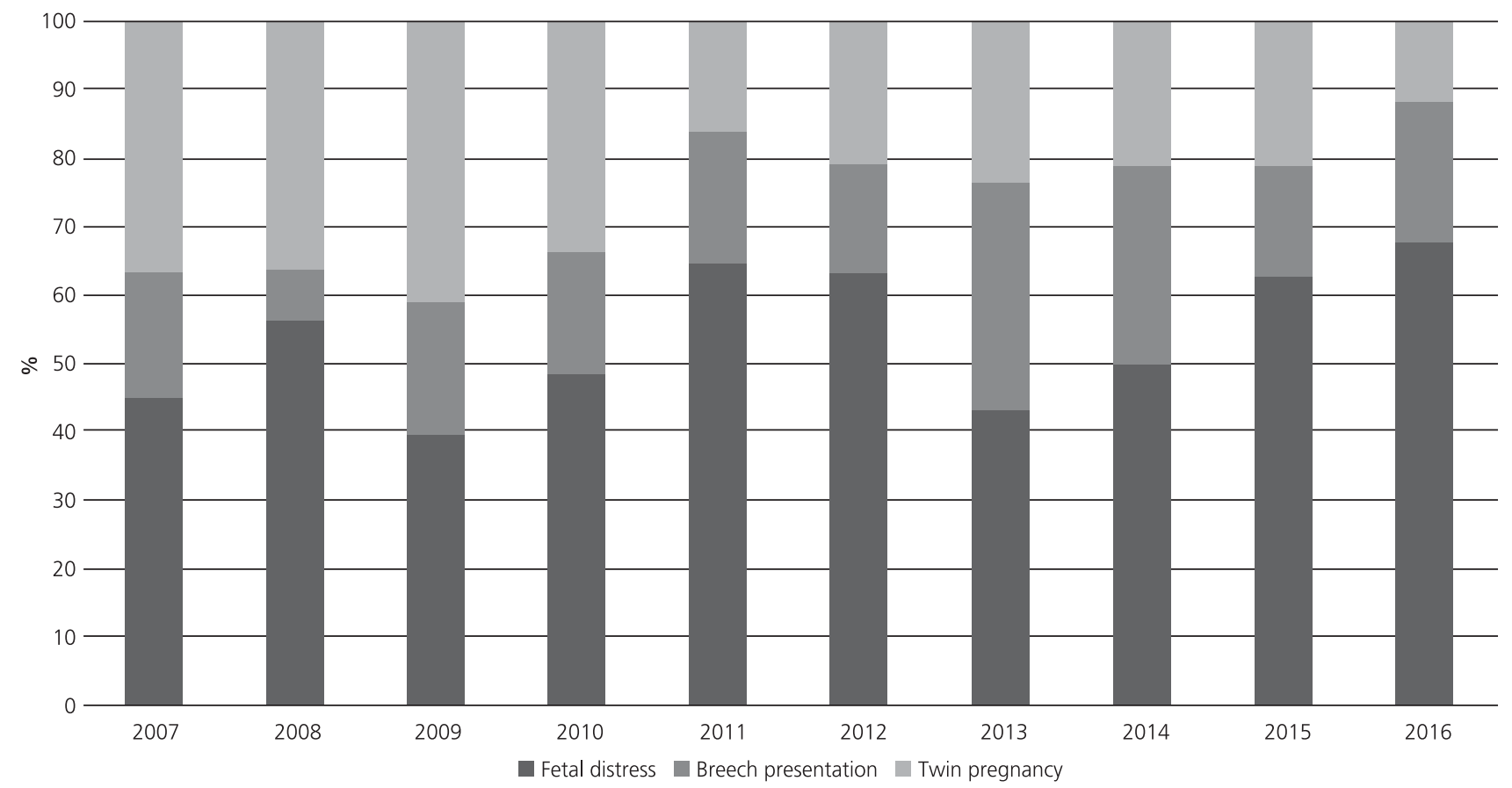

Fig. 2. Top 3 indication categories of primary cesarean section in preterm cases. 
Table 3. Comparison of maternal, fetal and obstetric characteristics in top 5 indication categories.

\begin{tabular}{|c|c|c|c|c|c|c|c|}
\hline Characteristics & & $\begin{array}{l}\text { Dystocia } \\
(n=1182)\end{array}$ & $\begin{array}{l}\text { Fetal distress } \\
\qquad(n=648)\end{array}$ & $\begin{array}{l}\text { Breech presentation } \\
\qquad(n=390)\end{array}$ & $\begin{array}{l}\text { Twin pregnancy } \\
\qquad(n=263)\end{array}$ & $\begin{array}{l}\text { Macrosomic fetus } \\
\qquad(n=239)\end{array}$ & p-value \\
\hline Maternal age (year) & & $\begin{array}{c}29.2 \pm 4.9 \\
(15-47)\end{array}$ & $\begin{array}{c}28.8 \pm 5.2 \\
(16-46)\end{array}$ & $\begin{array}{c}29.1 \pm 5.4 \\
(17-44)\end{array}$ & $\begin{array}{c}29.6 \pm 5.7 \\
(17-51)\end{array}$ & $\begin{array}{c}29.3 \pm 5.4 \\
(17-42)\end{array}$ & 0.793 \\
\hline Newborn weight (g) & & $\begin{array}{c}3417 \pm 462 \\
(1400-5160)\end{array}$ & $\begin{array}{l}2640 \pm 893 \\
(502-4750)\end{array}$ & $\begin{array}{l}2945 \pm 760 \\
(700-4900)\end{array}$ & & $\begin{array}{c}4138 \pm 316 \\
(3590-5580)\end{array}$ & $<0.0001$ \\
\hline Parity condition & $\begin{array}{l}0 \\
\geq 1\end{array}$ & $\begin{array}{c}1047(88.6) \\
135(11.4)\end{array}$ & $\begin{array}{l}492(75.9) \\
156(24.1)\end{array}$ & $\begin{array}{l}292(74.9) \\
98(25.1)\end{array}$ & $\begin{array}{l}218(82.8) \\
45(17.2)\end{array}$ & $\begin{array}{l}147(61.5) \\
92(38.5)\end{array}$ & $<0.0001$ \\
\hline Fetal sex & $\begin{array}{l}\text { Female } \\
\text { Male }\end{array}$ & $\begin{array}{l}537(45.4) \\
638(54.6)\end{array}$ & $\begin{array}{l}298(46.0) \\
350(54.0)\end{array}$ & $\begin{array}{l}197(50.5) \\
193(49.5)\end{array}$ & & $\begin{array}{l}99(41.4) \\
140(58.6)\end{array}$ & 0.026 \\
\hline Week of gestation & $\begin{array}{l}\text { Preterm } \\
\text { Term }\end{array}$ & $\begin{array}{c}22(1.9) \\
1160(98.1)\end{array}$ & $\begin{array}{l}175(27.0) \\
473(73.0)\end{array}$ & $\begin{array}{l}63(16.2) \\
327(83.8)\end{array}$ & $\begin{array}{c}94(35.7) \\
169(64.3)\end{array}$ & $\begin{array}{c}0(0.0) \\
239(100)\end{array}$ & $\begin{array}{l}<0.0001 \\
<0.008\end{array}$ \\
\hline Conception type & $\begin{array}{l}\text { Spontaneous } \\
\text { Assisted } \\
\text { reproductive } \\
\text { technology (IUI/IVF) }\end{array}$ & $\begin{array}{c}1142(96.6) \\
40(3.4)\end{array}$ & $\begin{array}{c}628(96.9) \\
20(3.1)\end{array}$ & $\begin{array}{c}379(97.2) \\
11(2.8)\end{array}$ & $\begin{array}{l}163(62.0) \\
100(38.0)\end{array}$ & $\begin{array}{c}235(98.3) \\
4(1.7)\end{array}$ & $<0.0001$ \\
\hline
\end{tabular}

When the changes in categories of the top 5 indication group for PCS cases were analyzed by the years, it was seen that dystocia group started to decrease after 2011, and regressed to $19.5 \%$ from $48.4 \%$ ( $<<0.0001$ ) (Table 1 and Fig. 1). Fetal distress category expanded between 2007 and 2009, narrowed between 2010 and
2013 ( $\mathrm{p}<0.0001)$ and then remained same relatively among other groups (Table 1 and Fig. 1). There was no significant change in the rate of PCS due to breech presentation during the study period; it reached its lowest level (7.4\%) in 2010 and its highest level (13.2\%) in 2016; however, this change was not statistically signifi-

Table 4. Procedures to be performed and actions to be taken to decrease the rates of primary cesarean section safely.

\begin{tabular}{ll}
$\begin{array}{ll}\text { Indication category of primary cesarean } \\
\text { section and the rate in total number }\end{array}$ & Recommendation and procedure \\
\hline Dystocia & Improving diagnosis criteria and determining reliable threshold values for the definition of failure to progress \\
& Accurate timing for hospitalization at delivery room \\
& Active labor follow-up \\
& Determining induction and augmentation criteria \\
\hline Fetal distress & Determining induction and augmentation criteria \\
& Standard guidelines and management algorithms for correct interpretation of fetal heart rate traces \\
& Amnioinfusion applications for repetitive variable decelerations \\
& Preventing preterm labor \\
& Protecting placental function and preventing fetal growth retardation \\
\hline Breech presentation & External cephalic version efforts \\
\hline Twin pregnancies & Proper selection and correct implementation of fertility support treatments \\
& Optimizing embryo transfer numbers \\
& Maintaining vaginal labor option in vertex-vertex presentations \\
\hline Macrosomic fetus & Proper nutrition during pregnancy \\
& Training for movement and lifestyle during pregnancy \\
& Glucose intolerance and diabetes screening \\
& Strict glycemic control in gestational diabetes cases \\
& Screening and following up thyroid functions \\
\hline Severe preeclampsia and eclampsia & Preeclampsia prediction and prophylaxis studies \\
\hline Fetal anomalies & Randomized controlled studies for the safety of vaginal labor in fetal anomaly types \\
& Establishing centers specialized on the delivery of fetuses with anomaly \\
\hline & \\
\hline
\end{tabular}


cant $(\mathrm{p}=0.109)$. Twin pregnancies remained stable between 2007 and 2010; it decreased as absolute number after 2010, but its rate within other groups did not change relatively $(\mathrm{p}=0.051)$. PCS labors performed due to the indication of macrosomic fetus increased greatly during 2013-2014, and reached its highest level $(16.3 \%)$ in $2016(\mathrm{p}<0.0001)$ (Table 1 and Fig. 1).

\section{Discussion}

In order to understand to what extent the rates of cesarean section labors can be decreased, it is necessary to determine the reasons for primary cesarean section. In their major retrospective cohort analysis within the scope of Safe Labor Consortium in the USA, Boyle et al. assessed 34,484 indications of primary cesarean section. $^{[1]}$ As the most common PCS indications, they reported non-progressive labor (35.4\%), non-reassuring fetal heart rate trace $(27.3 \%)$ and fetal malpresentations $(18.5 \%)$, and stated that the distributions varied according to the parity. ${ }^{[1,2]} 45.6 \%$ of all PCS labors were carried out on cases which were primiparous term singleton pregnancies and had cephalic presentation. This rate represents PCS cases which can be prevented somehow.

In a study conducted on more than 200,000 cesarean section cases in 19 hospitals between 2002 and 2008 in the USA, dystocia (47.1\%) was found as the most common indication of intrapartum cesarean section labors. ${ }^{[20]}$ Dystocia was followed by non-reassuring fetal heart rate traces $(27.1 \%)$ and malpresentations (7.5\%). In cesarean sections performed before labor started, previous history of cesarean section (45\%) was followed by breech and other malpresentations (17.1\%). ${ }^{[2]}$ Our study was consistent with the literature and top 3 categories of PCS indications were dystocia, fetal distress and breech presentation (Table 1 and Fig. 1).

Dystocia is consisted of the combination of two subindications, which are the opinion of cephalopelvic disproportion and failure to progress. ${ }^{[10]}$ Failure to progress also has two sub-phases which are the failure of progress during the active stage of labor and failure to descend at the second stage of labor. ${ }^{[21]}$ Failure to progress is partially subjective and controversial diagnosis. Instead of waiting for 2 hours, which was the criterion used traditionally before proceeding with cesarean section when there were sufficient uterine contractions, waiting for 4 hours has helped to decrease the number of failure to progress diagnosis without any worsening in maternal and perina- tal outcomes. ${ }^{[2]}$ In a report presented by Safe Labor Consortium in the USA argued that the definitions of labor progression should be updated and they should be extended slightly. ${ }^{[23]}$ Unlike the information based on classical Friedman's curves, it was observed that $0.5 \mathrm{~cm} / \mathrm{h}$ dilatation rate is normal sub-limit for cervical dilatation during active phase in both nulliparous and multiparous cases, and it can be seen during safe labor. ${ }^{[23]}$ In another study investigating the first stage of labor, it was concluded that the definition of failure to progress under 5 $\mathrm{cm}$ should not be used. ${ }^{[24]}$ Safe Labor Consortium recommends $6 \mathrm{~cm}$ for this diagnosis. ${ }^{[23]}$ Similar studies were conducted for the definition of duration of the second stage of labor and it was reported that keeping the maternal pushing effort as long as fetal heart rates are reassuring decreases the rates of cesarean section labors due to dystocia without any worsening in maternal and fetal outcomes. ${ }^{[25]}$ When considered from this point of view, dystocia is one of the most subjective indications due to the reasons such as being controversial in terms of diagnosis criteria among PCS indications and being open for personal opinions for considering whether a case have these criteria or not. ${ }^{[10]}$ The lack of reliable and high quality evidences particularly for the definition of non-progressive labor makes this diagnosis subjective. ${ }^{[10]}$ In this regard, it would be widely accepted that dystocia is one of the most difficult topics for decreasing the number of PCS (Table 4).

The greatest 2 nd category among PCS indications is the cesarean sections carried out due to fetal distress and non-reassuring fetal heart rate traces. ${ }^{[8]}$ Labor follow-up by EFM has been almost a routine practice in the world and Turkey and this increased PCS rates without any provable improvement in the neonatal outcomes. ${ }^{[12]}$ In our study, we analyzed and interpreted fetal distress cases according to triple category system of ACOG except for 2007. After its recommendation update, ACOG grouped fetal heart rate traces under 3 categories. ${ }^{[26]}$ Category 3 is an abnormal category which requires intervention, because fetal heart rate patterns in this category may be associated with the $\mathrm{pH}$ of abnormal neonatal umbilical cord, encephalopathy, and cerebral palsy. ${ }^{[26]}$ When corrective primary approaches (positioning pregnant woman on side-lying, investigating and eliminating hypotension and tachysystole, and ruling out acute reasons such as cord prolapse) do not improve fetal heart rates, rapid interventions including cesarean section are required. ${ }^{[2]}$ Fetal heart rate traces which are 
recorded most frequently during labor are the patterns included in Category 2. ${ }^{[8,27]}$ These traces are usually temporary and requires follow-up, but they frequently turn into Category 1 safe traces. ${ }^{[28]}$ Category 3 traces being rare is interpreted in a way that PCS labors due to fetal distress are carried out mostly by Category 2 indication. $^{[4]}$ The decision of emergency cesarean section in the presence of Category 2 fetal heart rate traces is based on medicolegal concerns. Lack of valid scientific evidences on the capacity of these traces to predict newborn's condition and the absence of studies supporting the efficiency of corrective intrauterine approaches indicates that it is not easy to decrease the number of PCS practices under this matter in the near future. Doppler evaluation of prenatal arterial and venous areas and cerebroplacental rate evaluations in cases which require labor induction in particular offered first promising evidences to help interpreting these traces in a more rational way. ${ }^{[2]}$ Important evidences have been accumulated about the efficacy of amnioinfusion practices for repetitive variable decelerations which have almost never been carried out, and activities to decrease the need for cesarean section labors. ${ }^{[8]}$

Breech presentation is considered as one of the most objective categories, ${ }^{[9,10]}$ and we have not observed any significant change in the rate of PCS due to breech presentation during the study period. The rates of perinatal asphyxia, increase in the need for newborn intense unit, newborn trauma and neonatal death are significantly high in vaginally-delivered pregnancies, and therefore vaginal delivery is avoided in breech presentation cases. ${ }^{[16,17]}$ For such reasons, vaginal delivery in breech presentation cases is one of the vanishing skills of the obstetrics. With external cephalic version, rotating to vertex position and efforts to get a chance for vaginal delivery have become a discussion topic again. ${ }^{[8,10]}$ Breech presentation cases are among the preventable PCS indications due to the presence of this option and relatively successful results reported. ${ }^{[10]}$ Macrosomia or large infant suspicion is not accepted as a cesarean section indication directly. ${ }^{[8]}$ ACOG recommends cesarean section for fetuses equal to or over $4500 \mathrm{~g}$ in diabetic cases and only for fetuses equal to or over $5000 \mathrm{~g}$ in non-diabetic cases in order to prevent birth traumas such as shoulder dystocia and permanent brachial plexus paralysis. ${ }^{[30]}$ Even for these thresholds, the positive impacts of cesarean section on neonatal outcomes are controversial. ${ }^{[31]}$ Ultrasonographic measurement of estimated fetal weights in the last weeks of gesta- tion can be quite misleading, and together with medicolegal concerns, $4000 \mathrm{~g}$ is preferred as the threshold in the daily obstetric practices for the suspicions about macrosomic fetus. In our study, 162 (67.8\%) of 239 cases which underwent PCS due to macrosomic fetus were $4000 \mathrm{~g}$ and above, 77 (32.2\%) cases were below $4000 \mathrm{~g}$. Considering the cases completely consistent with ACOG criteria, there were 3 cases which were non-diabetic and over $5000 \mathrm{~g}$ and 7 cases which were diabetic and over $4500 \mathrm{~g}$. These numbers indicate the margin of error for estimated fetal weight measurements and the use of lower threshold values in routine clinical practice such as 4000 g. In the retrospective cohort analysis of Boyle et al. including 38,484 PCS cases, newborn weight was below $4000 \mathrm{~g}$ in $41.9 \%$ of the cases which underwent cesarean section due to suspected macrosomia. ${ }^{[1]}$

One of the views on decreasing cesarean section rates due to macrosomia and macrosomia suspicion is to compare labor induction and follow-up options in pregnancies which are found to have fetuses large for gestational age. A prospective randomized controlled study on this issue reported that labor induction compared to follow-up approach decreased the rates of shoulder dystocia and the need for cesarean section in fetuses which are close to the term and large for gestational age. ${ }^{[19]}$ The fetus to be born being $4000 \mathrm{~g}$ and above seems to be among other indications and affect them. In the cases which underwent PCS due to dystocia, $90(6.1 \%)$ fetuses were $\geq 4000 \mathrm{~g}$ and 338 (28.6\%) fetuses were $\geq 3700 \mathrm{~g}$. Considering the entire cohort, 277 (8.5\%) cases were born $\geq 4000 \mathrm{~g}$, and 705 (21.4\%) cases were born $\geq 3700 \mathrm{~g}$. Fetuses having such weights may contribute to all diagnosis groups, and particularly non-progressive labor and cephalopelvic disproportion. The rates of preferring cesarean section deliveries in twin pregnancies have increased gradually, and this increase has reached to $70 \%$ even in cases where presenting fetus is on vertex position. ${ }^{[32]}$ As in head presentation of presenting fetus, it is known that cesarean section does not improve perinatal outcomes in twin pregnancies. ${ }^{[8]}$ In twin pregnancies, particularly in cases where first fetus is on vertex position, vaginal delivery should be recommended to pregnant women. During obstetrics specialization and residency, sufficient training and upskilling on delivery of twin pregnancies should be provided, and continuing education programs should be established to preserve this experience (Table 4). 
The rates of cesarean section labors are higher both in premature preterm cases ( $<34$ weeks) and late preterm cases (34-36 weeks) than term cases. ${ }^{[21]}$ In the large-scale cohort of Boyle et al., 21.6\% of the cesarean section cases were preterm cases ( $<37$ weeks and $0 / 7$ day $(\mathrm{s})){ }^{[1]}$ In our study, $15.0 \%$ of the cases were preterm cases (Table 2).

The studies investigating the potential relationship between cesarean section rates and characteristics of pregnant women showed that there was no correlation between PCS rates and ages, weights and ethnic origins of pregnant women. ${ }^{[3]} \mathrm{We}$ also did not find any significant difference in our study between the groups in terms of the mean age of pregnant women (Table 3).

In our study, we did not analyze the cases by the subcategories such as spontaneous labor and labor induction. Labor induction was considered as a risk factor for labor by cesarean section until recent prospective randomized controlled studies and their meta-analyses. ${ }^{[8]}$ However, when labor induction cases are compared to with the cases who are just followed up and are the actual equivalents instead of the spontaneous labor cases, it is seen that the rates of cesarean section did not increased but decreased on the contrary. ${ }^{[34]}$

\section{Conclusion}

World Health Organization reported that ideal rate of cesarean section is about $15 \%$, and recommended to keep PCS rates under control to reach this rate. ${ }^{[21]}$ Investigating PCS indication categories is the first step to take in order to reach this goal. The data to be obtained in this way may contribute to the development of strategies to decrease PCS rates.

Conflicts of Interest: No conflicts declared.

\section{References}

1. Boyle A, Reddy UM, Landy HJ, Huang CC, Driggers RW, Laughon SK. Primary cesarean delivery in the United States. Obstet Gynecol 2013;122:33-40.

2. Organisation for Economic Co-operation and Development [Internet]. Health data 2015-frequently requested data. Available from: https://data.oecd.org/healthcare/caesareansections.htm

3. Solheim K, Esakoff T, Little S, Cheng YW, Sparks TN, Caughey AB. The effect of cesarean delivery rates on the future incidence of placenta previa, placenta accreta, and maternal mortality. J Matern Fetal Neonatal Med 2011;24:1341-6.
4. Barber EL, Lundsberg LS, Belanger K, Pettker CM, Funai EF, Illuzzi JL. Indications contributing to the increasing cesarean delivery rate. Obstet Gynecol 2011;118:29-38.

5. Sebastiao YV, Womack L, Vamos CA, Louis JM, Olaoye F, Caragan T, et al. Hospital variation in cesarean delivery rates: contribution of individual and hospital factors in Florida. Am J Obstet Gynecol 2016;214:123.e1-123.e18.

6. ACOG Committee on Practice Bulletins - Obstetrics. ACOG Practice Bulletin No. 107: Induction of labor. Obstet Gynecol 2009;114:386-97.

7. Mancuso MS, Rouse DJ. Cesarean delivery for abnormal labor. Clin Perinatol 2008;35:479-90.

8. American College of Obstetricians and Gynecologists (College); Society for Maternal-Fetal Medicine, Caughey AB, Cahill AG, Guise JM, Rouse DJ. Safe prevention of the primary cesarean delivery. Am J Obstet Gynecol 2014;210:179-93.

9. Turkish Perinatology Society. Practical guideline for labor. Perinatal Journal 2009;17:35-58.

10. Tita AT. When is primary cesarean appropriate: maternal and obstetrical indications. Semin Perinatol 2012;36:324-7.

11. Simpson LL. When is primary cesarean appropriate: fetal indications. Semin Perinatol 2012;36:328-35.

12. Alfirevic Z, Devane D, Gyte GM. Continuous cardiotocography (CTG) as a form of electronic fetal monitoring (EFM) for fetal assessment during labour. Cochrane Database Syst Rev 2013;5:CD006066.

13. American College of Obstetricians and Gynecologists; Society for Maternal-Fetal Medicine. ACOG Practice Bulletin No. 144: Multifetal gestations: twin, triplet, and higher-order multifetal pregnancies. Obstet Gynecol 2014;123:1118-32.

14. Özkaya MO, Sezik M, Kaya H. Mode of delivery in multiple pregnancies. Perinatal Journal 2005;13:187-90.

15. Hofmeyr GJ, Kulier R, West HM. External cephalic version for breech presentation at term. Cochrane Database Syst Rev 2015;4:CD000083.

16. Baksu A, Şaşmazlar A, Tekelioğlu M, Özsoy S, Göker N. Makat prezentasyonlarında doğum şeklinin fetal ve maternal sonuçlarla ilişkisi . Perinatoloji Dergisi 2004;12:117-22.

17. Yıldırım G, Özdemir İA, Aslan H, Gülkılık A. Early neonatal outcomes of term breech delivery. Perinatal Journal 2006;14 $66-72$.

18. Boulvain M, Irion O, Dowswell T, Thornton JG. Induction of labour at or near term for suspected fetal macrosomia. Cochrane Database Syst Rev 2016;5:CD000938.

19. Boulvain M, Senat MV, Perrotin F, Winer N, Beucher G, Subtil D, et al.; Groupe de Recherche en Obstétrique et Gynécologie (GROG). Induction of labour versus expectant management for large-for-date fetuses: a randomised controlled trial. Lancet 2015;385:2600-5.

20. Zhang J, Troendle J, Reddy UM, Laughon SK, Branch DW, Burkman R, et al.; Consortium on Safe Labor. Contemporary cesarean delivery practice in the United States. Am J Obstet Gynecol 2010;203:326.e1-326.e10. 
21. Dresang LT, Leeman L. Cesarean delivery. Prim Care 2012; 39:145-65.

22. Rouse DJ, Weiner SJ, Bloom SL, Varner MW, Spong CY, Ramin SM, et al.; Eunice Kennedy Shriver National Institute of Child Health and Human Development (NICHD) Maternal-Fetal Medicine Units Network (MFMU). Failed labor induction: toward an objective diagnosis. Obstet Gynecol 2011;117:267-72.

23. Zhang J, Landy HJ, Branch DW, Burkman R, Haberman S, Gregory KD, et al.; Consortium on Safe Labor. Contemporary patterns of spontaneous labor with normal neonatal outcomes. Obstet Gynecol 2010;116:1281-7.

24. Zhang J, Troendle J, Mikolajczyk R, Sundaram R, Beaver J, Fraser $\mathrm{W}$. The natural history of the normal first stage of labor. Obstet Gynecol 2010;115:705-10.

25. Shields SG, Ratcliffe SD, Fontaine P, Leeman L. Dystocia in nulliparous women. Am Fam Physician 2007;75:1671-8.

26. Macones GA, Hankins GD, Spong CY, Hauth J, Moore T. The 2008 National Institute of Child Health and Human Development workshop report on electronic fetal monitoring: update on definitions, interpretation, and research guidelines. Obstet Gynecol 2008;112:661-6.

27. Cahill AG, Roehl KA, Odibo AO, Macones GA. Association and prediction of neonatal acidemia. Am J Obstet Gynecol 2012;207:206.e1-8.
28. American College of Obstetricians and Gynecologists. ACOG Practice Bulletin No. 106: Intrapartum fetal heart rate monitoring: nomenclature, interpretation, and general management principles. Obstet Gynecol 2009;114:192-202.

29. DeVore GR. The importance of the cerebroplacental ratio in the evaluation of fetal well-being in SGA and AGA fetuses. Am J Obstet Gynecol 2015;213:5-15.

30. American College of Obstetricians and Gynecologists. Fetal macrosomia: ACOG practice bulletin no. 22. Washington, DC: ACOG; 2000.

31. Little SE, Edlow AG, Thomas AM, Smith NA. Estimated fetal weight by ultrasound: a modifiable risk factor for cesarean delivery? Am J Obstet Gynecol 2012;207:309.e1-6.

32. Lee HC, Gould JB, Boscardin WJ, El-Sayed YY, Blumenfeld YJ. Trends in cesarean delivery for twin births in the United States: 1995-2008. Obstet Gynecol 2011;118:1095-101.

33. Declercq E, Menacker F, Macdorman M. Maternal risk profiles and the primary cesarean rate in the United States, 1991-2002. Am J Public Health 2006;96:867-72.

34. Darney BG, Snowden JM, Cheng YW, Jacob L, Nicholson JM, Kaimal A, et al. Elective induction of labor at term compared with expectant management: maternal and neonatal outcomes. Obstet Gynecol 2013;122:761-9. 